\title{
BUSINESS MODEL UNTUK MENCIPTAKAN STRATEGI BUSINESS LONGEVITY BAGI KAMPUNG WISATA
}

\author{
Nila Firdausi Nuzula ${ }^{1}$, Esti Junining ${ }^{1}$, Isti Purwaningtyas ${ }^{1}$, Didik Hartono ${ }^{1}$ \\ ${ }^{1}$ Universitas Brawijaya, Malang, Indonesia \\ nilafia@ub.ac.id
}

\begin{abstract}
Abstrak: Pada tahun 2007, masyarakat Dusun Kungkuk, Desa Punten, Kota Batu mengembangkan kampung wisata secara mandiri. Tokoh masyarakat dan penggerak usaha wisata berhasil mengajak masyarakat lokal untuk mengembangkan berbagai paket wisata yang fokus menawarkan pengalaman hidup di kampung kepada wisatawan. Namun, terjadinya pandemi menjadikan usaha wisata terhenti. Inisiatif untuk membangkitkan kembali partisipasi aktif masyarakat dusun hanya bertumpu kepada tokoh masyarakat dan inisiator kampung wisata. Para pemuda belum memiliki kemauan dan insiatif dalam melakukan promosi untuk membangkitkan dan meningkatkan skala usaha wisata. Pemahaman dan pengetahuan para pemuda kampung tentang prinsip dasar usaha wisata belum memadai dan merata. Untuk membantu mengurangi kekhawatiran tokoh masyarakat dan penggerak usaha wisata tentang keberlangsungan usaha (business longevity) Kampung Wisata Kungkuk, pengabdian masyarakat ini dilakukan untuk mengenalkan prinsip dasar usaha wisata berbasis konsep business model canvas (BMC) kepada para pemuda desa pelaku usaha wisata. Dengan menerapkan metode Participatory Action Research (PAR), para pemuda diajak untuk berdiskusi aktif menentukan sembilan unsur business canvas. Hasil diskusi tersebut menjadi dasar identifikasi kekuatan (strength), kelemahan (weakness), kesempatan (opportunity) dan ancaman (threat) dan selanjutnya menjadi data untuk pengembangan strategi bisnis. Tim pengabdian membantu menerjemahkan berbagai usulan pemuda desa menjadi empat strategi pengembangan bisnis, yaitu competitive, invasive, diversification, dan defensive strategies. Salah satu rekomendasi kepada para pemuda kampung wisata adalah memperkuat komitmen dan mengembangkan kesepakatan bersama tentang langkah apa yang perlu diambil untuk menjaga dinamika dan kelangsungan usaha Kampung Wisata Kungkuk.
\end{abstract}

Kata Kunci: kampung wisata, model bisnis canvas, penelitian tindakan partisipatif

\begin{abstract}
In 2007, the local community in Kungkuk, Punten, Batu City developed a tourism village through participative actions. The business was running well before the Covid-19 pandemic. Community leaders and tourism initiators have succeeded in getting local people to create various tour packages that focus on offering tourists the experience of living in a village. However, the pandemic brought the tourism to a halt. The leaders and tourism entrepreneurs are worried about the business longevity of kampung wisata. Even before the pandemic, the tourism development tends to be stagnant, and its continuity seems to rely only on the leaders. As the actors of the business activities, the youths do not have adequate knowledge and understanding of the basic principles of tourism business. In this case, a community program was held to introduce the business model canvas (BMC) concept to the youths to overcome the problems and take advantage of the pandemic period. By applying participatory action research $(P A R)$, the youths were invited to have an active discussion determining the nine elements of the business canvas. The discussion resulted in the basis for identifying strengths, weaknesses, opportunities, and business threats. It then becomes factual information for developing alternatives of business strategies. We help the youths translate the data into four business strategies: competitive, invasive, diversification, and defensive. The program recommends some critical points to the youths; strengthen their commitment and make a consensus on what actions are required to maintain the dynamics and continuity of Kampung Wisata Kungkuk.
\end{abstract}

Keywords: village tourism, business model canvas, participatory action research 


\section{Pendahuluan}

Dokumen rencana strategis Dinas Pariwisata Kota Batu pada periode 2017-2022 menyebutkan adanya dua tujuan pengembangan pariwisata kota tersebut, yaitu peningkatan pelestarian dan pengembangan budaya daerah, serta peningkatan aktivitas perekonomian yang inklusif berkelanjutan pada sektor pariwisata. Dengan dua tujuan tersebut, pemerintah kota mengembangkan berbagai program terkait pembinaan dan pengembangan budaya, serta program pembinaan pengembangan produk dan destinasi pariwisata. Program pemerintah tersebut cukup efektif, dimana hingga tahun 2018 terdapat 14 desa dan kampung wisata di wilayah pemerintahan kota (Dinas Pariwisata Kota Batu, 2018). Salah satu kampung wisata yang menjadi andalan pemerintah kota dan disebutkan dalam dokumen Rencana Strategis Dinas Pariwisata adalah Kampung Wisata Kungkuk, di Desa Punten, Kecamatan Bumiaji.

Letak Desa Punten ini strategis karena berada di antara dua gunung, yaitu Gunung Panderman yang berada di sebelah selatan, dan Gunung Arjuno yang berada di sebelah utara. kampung wisata Kungkuk terletak di Dusun Kungkuk, yang memiliki luas wilayah 14 hektar dan ketinggian geografis 950 mdpl. Masyarakat dusun bermata pencaharian sebagai petani jeruk dan sayur-sayuran. Dusun Kungkuk juga memiliki wilayah perbukitan hutan pinus yang berada dalam wilayah kewenangan Perum Perhutani Kesatuan Pemangku Hutan (KPH) Malang.

Kontur wilayah geografis tersebut menguntungkan bagi pengembangan destinasi wisata baru di Kota Batu. Di samping itu, pada tahun 2007, masyarakat petani apel mengalami penurunan harga dan kualitas produksi buah apel di pasaran, seiring dengan terjadinya peningkatan suhu udara yang mengakibatkan wilayah yang cocok ditanami pohon apel bergeser ke arah perbukitan yang lebih tinggi. Kondisi ini mendorong masyarakat dusun mulai beralih ke pertanian jeruk. Di sisi lain, potensi dan sumber daya alam di dusun Kungkuk memungkinkan masyarakat untuk mengembangkan Kampung Wisata Kungkuk. Hingga pada tahun 2020, Kampung Wisata tersebut telah menawarkan homestay dan beragam obyek wisata yang banyak dijual kepada tidak hanya masyarakat Malang Raya, tetapi juga di luar Propinsi Jawa Timur. Bahkan beberapa warga kampung mengaku mendapat tamu dari luar negeri. Hal ini dimungkinkan karena promosi produk kampung wisata tidak hanya melalui mulut ke mulut, tetapi juga menggunakan media sosial seperti Facebook dan Instagram.

Tetapi, pada saat terjadi pandemi Covid-19 di Indonesia sejak Maret 2020 pendapatan masyarakat pelaku wisata di Dusun Kungkuk menurun. Jumlah wisatawan berkurang drastis hingga nol wisatawan pada saat kebijakan lockdown dilaksanakan. Pembatasan pergerakan masyarakat berdampak pada pembatalan pesanan paket wisata dan homestay. Di masa pandemi, tokoh dusun dan perintis kampung wisata berusaha keras untuk menghidupkan kembali semangat pemuda kampung wisata untuk tetap mengelola dan mempromosikan layanan wisata. Tetapi, tokoh dusun dan perintis kampung wisata menyampaikan kepada penulis bahwa upaya pelestarian usaha kampung wisata hanya bertumpu pada tokoh masyarakat dan inisiator kampung wisata. Tokoh dusun merasa bahwa para pemuda kampung belum memiliki kemauan dan inisiatif untuk meningkatkan skala usaha wisata yang sudah ada. Demikian pula, menurut tokoh dusun, pemahaman dan pengetahuan tentang prinsip dasar 
usaha wisata juga belum memadai dan merata ke seluruh pemuda pelaku usaha wisata. Dampaknya potensi wisata terasa belum digali lebih banyak dan berkontribusi lebih banyak untuk meningkatkan kesejahteraan masyarakat Dusun Kungkuk. Kurangnya pengetahuan tentang proses bisnis kampung wisata ini dikhawatirkan berdampak pada keberlangsungan usaha (business longevity) kampung wisata.

Kurangnya pengetahuan para pelaksana kampung wisata ini telah diprediksi oleh beberapa penelitian terdahulu. Sharpley (2002) menjelaskan bahwa pelaku rural tourism semakin banyak seiring dengan penurunan kegiatan pertanian. Masyarakat petani kemudian mengembangkan usaha wisata yang relevan dengan kegiatan pertanian sebagai reaksi untuk menjaga pertumbuhan ekonomi desa dan melakukan diversifikasi usaha di wilayah desa. Tetapi, faktor penghambat pengembangan usaha wisata desa adalah kurangnya pelatihan dan pengetahuan pelaku usaha wisata pertanian. Salvatore, Chiodo, \& Fantini (2018) juga menyebutkan bahwa tantangan utama pengembangan wisata berbasis masyarakat berkaitan dengan keterbatasan pengetahuan, pengalaman, dan kepercayaan diri masyarakat lokal untuk mengelola sumber daya di wilayah mereka.

Tokoh dusun dan perintis kampung wisata menyampaikan kepada penulis bahwa mereka bermaksud untuk memanfaatkan masa nol wisatawan sebagai waktu yang tepat untuk dapat merekonstruksi model bisnis wisata mereka sedemikian rupa sehingga jika masa pandemi berakhir, masyarakat dapat mengandalkan tambahan pendapatan ekonomi dari layanan dan aktivitas wisata. Di masa pandemi, sumber pendapatan masyarakat dusun bertumpu pada hasil pertanian jeruk, sayur mayur, dan bunga. Berdasarkan kebutuhan ini, penulis bermaksud untuk mengajak masyarakat Kampung Wisata Kungkuk untuk mampu meredefinisikan model bisnisnya sedemikian rupa sehingga mampu beradaptasi secara fleksibel pada masa pandemi.

Artikel ini mendeskripsikan proses dan hasil pengenalan business model canvas (BMC) kepada kelompok masyarakat dengan tujuan agar masyarakat memiliki konsep yang memadai tentang pengembangan model bisnis pariwisata yang berkelanjutan yang berbasis pada masyarakat (sustainable community-based tourism business). Coes (2014) menjelaskan bahwa BMC adalah salah satu instrumen model bisnis (business model tools), yang bermanfaat untuk mengidentifikasi faktor ekonomi, operasi, dan strategi suatu organisasi usaha. Peneliti tersebut menjelaskan BMC membantu wirausahawan mengembangkan strategi bisnis setelah mereka mengetahui empat elemen kunci suatu bisnis, yaitu value proposition, pola relasi antara usaha bisnis dengan mitra kerja, proses bisnis yang bisa dilakukan saat ini, dan aspek keuangan. Strulak-Wojcikiewicz, et al. (2020) menggunakan BMC untuk mengembangkan tourism eplatform dengan alasan bahwa BMC memiliki keunggulan dalam hal penggunaan bahasa yang familiar dan meminta pengguna mengidentifikasi komponen bisnis yang menata ide-ide pengembangan strategi bisnis pada sektor pariwisata.

\section{Metode}

Pengabdian masyarakat ini bermaksud untuk mengenalkan BMC bagi kelompok sadar wisata (pokdarwis) Kampung Kungkuk. Dengan tujuan tersebut, metode yang digunakan 
penulis untuk melaksanakan program tersebut adalah participatory action research (PAR). Koch, Selim, \& Kralik (2002) menjelaskan bahwa PAR ini relevan dan tepat untuk mengajak masyarakat terlibat aktif untuk memahami akar masalah, merencanakan pengambilan aksi yang tepat untuk memecahkan masalah, dan mengevaluasi analisis mereka. Kelly (2005) menjelaskan bahwa metode PAR relevan sebagai proses pendidikan, dimana peneliti menggunakan kajian pustaka, survey, dan pertemuan dengan masyarakat untuk mendorong masyarakat memahami dan menjalankan suatu konsep.

Penerapan metode PAR dalam pengabdian masyarakat ini dilakukan dalam dua tahap utama, yaitu identifikasi kapasitas diri dan penentuan longevity strategy. Tetapi, sebelumnya, penulis melakukan wawancara dan observasi pendahuluan terhadap kondisi kampung dan tingkat partisipasi para pelaku kegiatan wisata di Kampung Kungkuk. Hal ini diperlukan untuk menentukan siapa peserta diskusi dan pola diskusi yang dinilai efektif sesuai dengan karakter masyarakat setempat. Rangkaian kegiatan wawancara dan observasi hingga pelaksanaan pengabdian dilaksanakan mulai awal Juni hingga pertengahan Oktober 2020.

Penulis melakukan wawancara terhadap informan kunci, yaitu tokoh dusun, perintis pelaku kegiatan wisata, dan ketua pokdarwis. Ketua pokdarwis menjelaskan bahwa sebenarnya pelaku wisata di kampung tersebut lebih banyak. Akan tetapi, dengan mempertimbangkan situasi pandemi, kesediaan dan kesesuaian agenda kegiatan, ketua pokdarwis mengusulkan 15 orang calon peserta diskusi. Peserta diskusi yang dipilih oleh ketua pokdarwis ini adalah para pemuda dusun pelaku utama dan memiliki kemampuan untuk menularkan pengetahuan kepada pelaku wisata yang lain yang berhalangan hadir. Para peserta adalah warga Kampung Kungkuk yang terlibat dan menjalankan berbagai paket wisata di daerah tersebut. Bentuk kegiatan wisata yang dijalankan warga tersebut beragam, meliputi 1) wisata edukasi bisnis, 2) wisata edukasi pertanian, 3) wisata petik buah apel, jeruk, dan bunga mawar, 4) wisata perah susu dan ternak hewan kelinci, 5) penyediaan homestay, 6) wisata ronda malam, 7) wisata berkuda, 8) wisata outbound dan camping, 9) wisata seni Tari Bambu Gila, Tari Santar, dan Kuda Lumping. Para pelaku wisata ini kemudian diundang untuk mengikuti diskusi dan pelatihan (Gambar 1).

Penulis menetapkan peserta dengan karakteristik tertentu karena berdasarkan Steyn, Rampa, \& Marais (2013), tahap penetapan dan identifikasi siapa peserta diskusi ini merupakan tahap krusial dan menentukan keberhasilan program kegiatan berbasis community involvement approach. Artinya, tahap ini menjadi faktor penentu efektifitas pelaksanaan PAR untuk mengenalkan dan mengajak peserta diskusi menggunakan konsep BMC dalam proses bisnis wisata di Kampung Wisata Kungkuk.

Pada implementasi PAR tahap pertama, yaitu identifikasi kapasitas diri, peneliti mengedarkan pertanyaan pre-test kepada peserta diskusi. Hasil pre-test sekaligus digunakan sebagai bahan diskusi untuk mengetahui pemahaman peserta diskusi terhadap konsep BMC. Di tahap ini, penulis juga mengidentifikasi masalah dan kapasitas masyarakat dalam mengembangkan usaha bisnis pariwisata yang berkelanjutan. Pada langkah kedua, penulis mengenalkan dan menjelaskan konsep dasar BMC. Penulis mengenalkan sembilan konsep dasar BMC dan memberikan contoh praktis dari setiap konsep berdasarkan informasi dan jawaban yang dilontarkan pada peserta diskusi. Sembilan konsep atau unsur BMC tersebut adalah key 
partners, key activities, value proposition, customer relationships, customer segments, key resources, channels, cost structures, dan revenue streams. Peserta kemudian diminta mensimulasikan instrumen BMC pada masing-masing bentuk kegiatan wisata yang dikelola dengan bahasa dan perspektif masing-masing. Selanjutnya peserta diminta menyampaikan hasil diskusi dan audiens diminta memberikan masukan dan evaluasi. Output dari tahap ini adalah kertas kerja sembilan unsur BMC yang telah diisi oleh para peserta.

Pada tahap kedua yaitu penentuan longevity strategy, penulis meminta peserta menggunakan hasil identifikasi sembilan unsur BMC sebagai masukan untuk menentukan strenghts (kekuatan), weaknesses (kelemahan), opportunities (kesempatan), dan threats (ancaman) atau SWOT Kampung Wisata Kungkuk, bukan analisis individual bentuk-bentuk wisata. Hal ini karena pengelolaan kampung wisata adalah di bawah satu pokdarwis, sehingga hasil SWOT diharapkan mampu membantu menentukan strategi pengembangan Kampung Wisata Kungkuk. Peserta juga diminta merumuskan alasan pemilihan strategi. Terakhir, penulis melakukan evaluasi pemahaman peserta terhadap BMC, penggunaan hasil identifikasi komponen bisnis sesuai BMC untuk mengidentifikasi SWOT, dan partisipasi peserta untuk menentukan strategi bisnis. Keseluruhan tahapan tersebut merupakan modifikasi dari tahap implementasi PAR sebagai aktivitas untuk mendefinisikan masalah masyarakat, merekomendasi aksi dan solusi, serta mengevaluasi pekerjaan sebagaimana disebutkan oleh Kelly (2005). Visualisasi tahap-tahap aktivitas pengabdian masyarakat ditunjukkan dalam Bagan 1 di bawah ini.

Identifikasi kapasitas diri

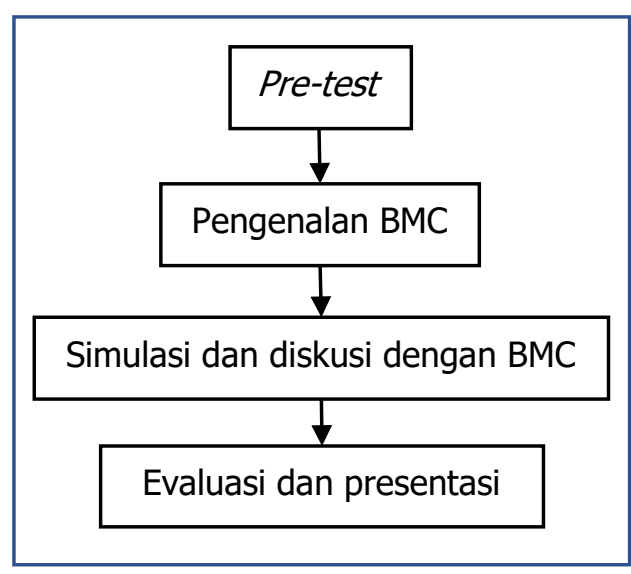

Tentukan longevity strategy

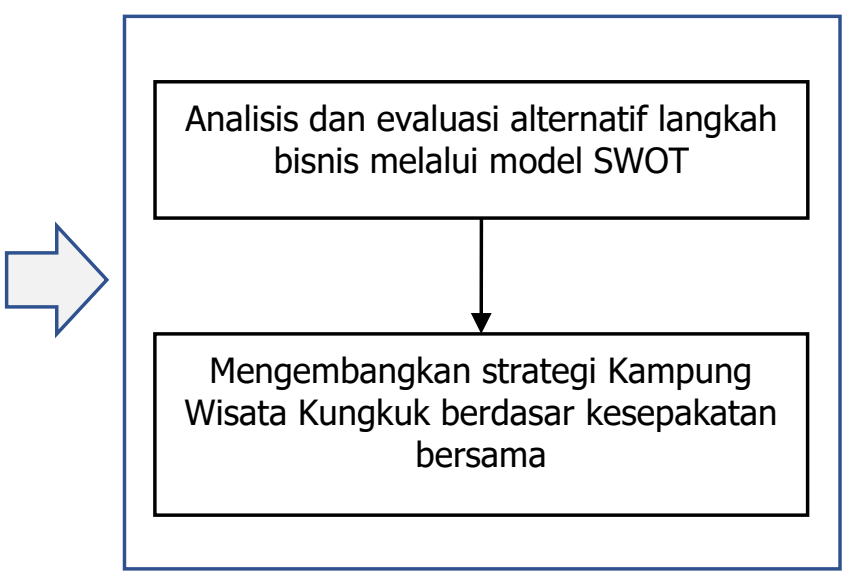

Bagan 1. Proses participatory action research

Sumber: Modifikasi dari Kelly (2005)

\section{Hasil dan Pembahasan}

Aktivitas pariwisata tidak terlepas dari pergerakan orang untuk mendatangi suatu tempat atau kelompok orang yang memiliki karakter tertentu. Dengan demikian, kegiatan pariwisata tidak terlepas dari partisipasi masyarakat destinasi wisata. Pola aktivitas di Dusun Kungkuk menunjukkan kontribusi pemuda pelopor atau penggerak wisata mengajak pemuda desa melakukan diversifikasi atraksi wisata berbasis pertanian dengan memanfaatkan kondisi 
geografis dan kemampuan penduduk Dusun. Peran tokoh kampung dan penggerak wisata ini signifikan dan terbukti mampu menggerakkan masyarakat Dusun menyiapkan fasilitas fisik dan meningkatkan pengetahuan berbisnis pariwisata. Realita ini mendukung pendapat Beeton (2006) bahwa aktivitas pariwisata menjadi instrumen penting bagi upaya-upaya peningkatan pembangunan masyarakat, terutama bagi masyarakat asli, desa dan terasing.

Partisipasi masyarakat untuk mengembangkan daerahnya menjadi lokasi wisata ini didorong pula oleh kebijakan pemerintah daerah Kota Batu. Situasi ini mendukung pernyataan Spirou (2011) bahwa perkembangan restrukturisasi wilayah geografis, revitalisasi wilayah perkotaan, dan hubungan antar masyarakat menjadikan perkembangan pariwisata di daerah perkotaan menjadi relevan dan berkembang pesat. Dusun Kungkuk yang berlokasi di wilayah Kota Batu menjadi salah satu destinasi turisme perkotaan. Dusun ini berkembang sebagai jawaban masyarakat untuk berwisata sambil menjalankan perjalanan bisnis atau memang untuk berlibur. Perkembangan ini tepat dan sesuai dengan maksud pemerintah kota mengembangkan ekonomi perkotaan melalui strategi investasi pada infrastruktur perkotaan dan memasarkan kota sebagai tempat hiburan.

Penulis menekankan urgensi tokoh masyarakat dan penggerak/pelopor wisata Dusun Kungkuk mengidentifikasi sumber daya yang terlibat dalam penyelenggaraan kampung wisata. Salah satu cara untuk mengidentifikasi sumber daya yang terlibat adalah dengan menggunakan business model canvas (BMC). Penulis berpendapat bahwa dengan mengidentifikasi faktorfaktor penggerak bisnis sebagaimana yang tertera dalam BMC, para pelaku wisata di Dusun Kungkuk mengidentifikasi dan mengeksploitasi potensi sumber daya internal dan eksternal yang terjangkau dalam memajukan kampung wisata. Konsep ini sejalan dengan pernyataan Napolitano, Marino, \& Ojala (2015) bahwa pengembangan strategi bisnis berbasis pada sumber daya, atau resource-based view (RBV), menjadi kunci penting mempertahankan bisnis dalam jangka panjang (business longevity).

Uraian berikut ini merupakan deskripsi hasil wawancara dan observasi terhadap tokoh masyarakat dan pelopor wisata Dusun Kungkuk yang sekaligus sebagai ketua pokdarwis. Kampung Wisata Kungkuk dipelopori oleh dua orang yang memiliki kapasitas pengetahuan yang memadai untuk menjalankan bisnis. Salah satunya pernah mendapatkan pembinaan ketrampilan pengembangan kewirausahaan dan kepariwisataan di tingkat nasional dan bahkan menjadi instruktur. Pelopor kampung wisata tersebut termasuk kader yang aktif mengembangkan pengetahuan praktis tentang menjalankan usaha wisata. Kader wisata ini pula yang bertindak sebagai marketer paket-paket wisata, sekaligus sebagai pelaku paket wisata edukasi bisnis dan menjalankan produksi kripik buah dan sayuran. Tetapi, di masa pandemi, kedua pelopor wisata tersebut berpendapat bahwa upaya mempertahankan dan mengembangkan bisnis kampung wisata perlu digerakkan serentak oleh seluruh pemuda dusun. Pengembangan bisnis membutuhkan dua macam pengetahuan, yaitu pengetahuan manajerial dan ketrampilan menyelenggarakan usaha homestay dan paket-paket wisata. Pemuda dusun sudah memiliki pengetahuan dan ketrampilan jenis kedua karena pada dasarnya mereka adalah petani dan paket wisata merupakan pengembangan dari usaha pertanian. Tetapi, mereka belum memiliki pengetahuan tata kelola usaha kampung wisata sebagai institusi usaha. 
Pelopor kampung wisata ini mempromosikan beragam paket wisata Kampung Wisata Kungkuk melalui laman media sosial, dan menitipkan brosur paket wisata ke biro travel. Ia pula yang membujuk agar jasa biro travel membawa turis mereka ke Kampung Wisata Kungkuk, sekaligus merancang paket wisata apa saja yang dapat ditawarkan kepada turis yang datang. Kader ini pula yang mengajak masyarakat Dusun Kungkuk untuk menyiapkan beragam paket wisata dan mengajak masyarakat untuk menyediakan ruangan di rumah nya disewakan sebagai tempat tinggal turis selama di Dusun Kungkuk (menyediakan homestay). Kader wisata ini membagikan pengetahuan tentang bagaimana menyediakan kamar yang memadai, terstandar dan memenuhi kebutuhan dasar wisatawan, serta mengajak anggota masyarakat lain untuk mengembangkan paket-paket wisata baru.

Proses diseminasi pengetahuan tersebut berlaku secara terus menerus sejak tahun 2007 hingga saat ini. Di sisi lain, kader wisata juga mendapatkan kesempatan untuk meningkatkan pengetahuannya melalui kepesertaan di berbagai pelatihan pengembangan bisnis wisata. Dengan proses seperti itulah, wajar kiranya pemuda pelaku wisata mudah dan cepat menerima informasi dan mengidentifikasi beberapa faktor penentu dalam konsep business model canvas, karena pada hakikatnya mereka terlibat dalam menjalankan faktor-faktor tersebut. Penulis menyimpulkan bahwa para peserta diskusi mampu melampaui tahap pertama dari implementasi PAR, yaitu tahap identifikasi kapasitas diri. Salah satu contoh hasil diskusi pemuda Kampung Wisata Kungkuk terkait sembilan komponen BMC untuk layanan penyediaan kamar tinggal atau homestay dapat dlihat pada Tabel 1. Uraian hasil diskusi pada setiap komponen BMC dijelaskan sebagai berikut.

\section{Key activities}

Menurut Coes (2014), aktivitas kunci (key activities) merupakan komponen terpenting yang menunjukkan proses bisnis apa yang dilakukan suatu usaha agar model bisnisnya berjalan baik. Aktivitas tersebut harus relevan dengan upaya-upaya menciptakan layanan yang berkualitas dan berkesan bagi pelanggan (value proposition). Berdasarkan penjelasan tersebut, penulis mengarahkan peserta diskusi untuk mengidentifikasi beragam aktivitas utama yang menjadikan paket wisata mereka unik. Sebagai contoh, aktivitas utama yang dilakukan penyedia layanan homestay adalah mengajak tamu untuk mengikuti kegiatan memasak atau berkebun. Penyedia homestay juga berkoordinasi dengan penyedia paket wisata lain seperti outbond dan camping, perah susu dan ternak kelinci, dan ronda malam guna memperkaya aktivitas wisata. Secara keseluruhan, aktivitas wisata ini ditujukan untuk memberikan pengalaman hidup dan beraktivitas seperti penduduk desa. Hal ini ditujukan untuk meningkatkan hubungan dengan pelanggan dan meningkatkan pengalaman berwisata yang berbeda. Aktivitas lain adalah meningkatkan kualitas dan ragam fasilitas homestay, misalnya penyediaan mesin pemanas air untuk mandi dan ruang kamar tidur dan ruang keluarga yang nyaman. Aktivitas ini berdampak pada kemudahan untuk membentuk value proposition. 
Tabel 1. Business Model Canvas penyediaan kamar homestay

\begin{tabular}{|c|c|c|c|c|}
\hline $\begin{array}{l}\text { Key Partners } \\
\text { 1. Host (penyedia } \\
\text { homestay) } \\
\text { 2. Perusahaan travel } \\
\text { (keahlian promosi) } \\
\text { 3. Petani/pemilik } \\
\text { kebun buah apel, } \\
\text { jeruk dan mawar } \\
\text { 4. Pemandu wisata }\end{array}$ & $\begin{array}{l}\text { Key Activities } \\
\text { 1. Membuat kegiatan bersama } \\
\text { antara host dan tamu } \\
\text { (memasak, berkebun, beternak) } \\
\text { 2. Memberi informasi dan } \\
\text { mengajak tamu mengikuti } \\
\text { kegiatan ronda malam, } \\
\text { outbound, perah susu, dan lain- } \\
\text { lain } \\
\text { 3. Menambahkan fasilitas di kamar } \\
\text { 4. Meningkatkan jaringan } \\
\text { distribusi (misal, buatlah } \\
\text { analisis data kota asal tamu, } \\
\text { bagaimana mereka mengetahui } \\
\text { layanan homestay) }\end{array}$ & \multirow{2}{*}{$\begin{array}{l}\text { Value Proposition } \\
\text { 1. Hubungan host-tamu yang ramah } \\
\text { dan berdasarkan kekeluargaan } \\
\text { 2. Pengalaman hidup di daerah yang } \\
\text { memiliki keistimewaan alam/atraksi } \\
\text { menarik } \\
\text { 3. Informasi dan rekomendasi tempat- } \\
\text { tempat menarik dan otentik yang } \\
\text { perlu dikunjungi pada kunjungan } \\
\text { berikutnya } \\
\text { 4. Pilihan rumah yang beragam sesuai } \\
\text { kebutuhan tamu } \\
\text { 5. Proses booking mudah } \\
\\
\text { Saran yang diberikan: } \\
\text { 1. Buatlah standar hospitality yang } \\
\text { berlaku untuk semua host } \\
\text { 2. Jaga keamanan dan kepercayaan } \\
\text { tamu secara serius }\end{array}$} & $\begin{array}{l}\text { Customer Relationships } \\
\text { 1. Penanganan komplain dengan } \\
\text { komunikasi yang baik } \\
\text { 2. Menjaga privasi data tamu } \\
\text { 3. Memberikan jaminan } \\
\text { keamanan tamu } \\
\text { 4. Gambarkan citra manajemen } \\
\text { yang baik di website }\end{array}$ & $\begin{array}{l}\text { Customer Segments } \\
\text { 1. Identifikasi tujuan } \\
\text { utama wisatawan } \\
\text { adalah untuk bisnis } \\
\text { atau memang untuk } \\
\text { wisata } \\
\text { 2. Identifikasi wisatawan } \\
\text { dalam konteks } \\
\text { demografi (single atau } \\
\text { keluarga atau } \\
\text { rombongan outbound } \\
\text { lembaga) } \\
\text { 3. Identifikasi wisatawan } \\
\text { dalam hal pendapatan } \\
\text { (sedang, menengah, } \\
\text { dst) }\end{array}$ \\
\hline \multicolumn{2}{|c|}{$\begin{array}{l}\text { Key Resources } \\
\text { 1. Network (host, agen perjalanan, pengelola atraksi } \\
\text { lokal) } \\
\text { 2. Daftar rumah } \\
\text { 3. Daftar event/kegiatan } \\
\text { 4. Konten website } \\
\text { 5. Data pelanggan } \\
\text { 6. Merek } \\
\text { 7. Website } \\
\end{array}$} & & \multicolumn{2}{|c|}{$\begin{array}{l}\text { Channels } \\
\text { 1. Booklet yang diletakkan di tempat-tempat wisata atau } \\
\text { dititipkan agen perjalanan } \\
\text { 2. Digital campaign (Facebook, Twitter, Instagram, dll) } \\
\text { 3. Word of mouth: minta pelanggan untuk menyebutkan } \\
\text { hashtag } \\
\text { Jika pelanggan sudah melakukan kontak, jaga hubungan baik } \\
\text { dengan menjaga kontinuitas media (WA email) }\end{array}$} \\
\hline \multicolumn{2}{|c|}{$\begin{array}{l}\text { Cost Structures } \\
\text { 1. Biaya operasional (biaya perbaikan infrastruktur, listrik, } \\
\text { gas, dll) } \\
\text { 2. Biaya mengikuti pelatihan }\end{array}$} & \multicolumn{3}{|c|}{$\begin{array}{l}\text { Revenue Streams } \\
\text { 1. Tentukan penerimaan setelah memperhitungkan biaya yang dikeluarkan oleh host } \\
\text { 2. Berikan kebijakan ongkos yang berbeda jika kunjungan tamu adalah kunjungan kedua } \\
\text { 3. Berikan kebijakan biaya (dari sisi tamu) jika ada pembatalan } \\
\text { 4. Tentukan biaya tambahan untuk layanan ekstra (misal mengantar tamu untuk event tertentu) }\end{array}$} \\
\hline
\end{tabular}

Sumber: Data diolah (2021) 


\section{Value proposition}

Peserta diskusi mampu menentukan nilai (value) yang diciptakan secara berbeda untuk wisatawan sesuai dengan layanan wisata yang ditawarkan. Sebagai contoh, para penyedia homestay dapat menyebutkan bahwa value proposition mereka adalah terciptanya hubungan antara host dan tamu yang ramah dan berdasarkan kekeluargaan dan pengalaman hidup di daerah yang memiliki keistimewaan alam dan atraksi menarik. Pernyataan value proposition ini didukung oleh adanya pilihan rumah yang beragam sesuai dengan kebutuhan dan ketersediaan dana wisatawan dengan proses booking yang mudah. Value proposition lain adalah adanya informasi dan rekomendasi tempat-tempat menarik dan otentik yang dapat didatangi pada kunjungan berikutnya. Ketua pokdarwis berharap bahwa para penyedia homestay tetap menjunjung tinggi value proposition ini karena hal tersebut menjadi ujung tombak dan keunggulan bersaing layanan penyediaan kamar tinggal di Kampung Wisata Kungkuk. Hal ini sesuai dengan penjelasan Coes (2014) bahwa value proposition adalah komponen terpenting dalam BMC dan memberikan pedoman bagaimana memberi layanan kepada pelanggan. Jika para penyedia layanan wisata tidak mampu menerapkan value proposition ini, maka keberlangsungan usaha dapat terancam.

\section{Customer relationship}

Unsur ini merupakan salah satu faktor yang mudah untuk dikenali oleh para peserta diskusi. Mereka mampu mengidentifikasi bagaimana menjaga hubungan baik dengan pelanggan, yaitu menjaga sopan santun saat berkomunikasi, menjaga privasi dan kenyamanan bagi wisatawan, memberikan citra baik antara yang disampaikan pada brosur dan media massa dengan realita. Peserta diskusi juga menyebutkan perlunya menindaklanjuti komplain sesegera mungkin dengan cara yang baik dan perlunya menjaga kebersihan lingkungan Dusun Kungkuk. Upaya menjalin hubungan dengan pelanggan ini sesuai dengan penjelasan Coes (2014), bahwa komunikasi aktif dan berorientasi melayani pelanggan ini penting untuk menyampaikan value proposition. Berdasarkan referensi tersebut, penulis menyarankan peserta diskusi agar secara aktif dan dinamis menyesuaikan cara berkomunikasi dan menjangkau pelanggan sejalan dengan kebiasaan terbaru pelanggan.

\section{Customer segments}

Secara umum, peserta diskusi mampu mengidentifikasi siapa pelanggan mereka. Mereka juga menyampaikan bahwa masyarakat saat ini mampu menyisihkan pendapatan untuk kepentingan rekreasi. Faktor ini relevan dengan upaya untuk mendorong pengembangan Kampung Wisata Kungkuk. Pemerintah Desa Punten menyambut angin segar ini dan bermaksud mengembangkan dusun-dusun lain di wilayah desa tersebut sebagai kampung wisata pula. Sebagaimana yang disampaikan oleh Spirou (2011), pemerintah kota menyadari potensi ekonomi yang tersimpan dari identitas budaya dan destinasi wisata yang dimiliki masing-masing wilayah, dan bermaksud untuk menerapkan kebijakan pembangunan sektor pariwisata. Pendapatan pemerintah dari sektor ini diharapkan mampu kembali ke masyarakat dalam bentuk transformasi sosial dan ekonomi masyarakat kota itu sendiri. 


\section{Key resources}

Menurut Coes (2014), sumber daya utama (key resources) meliputi sumber daya yang berkontribusi untuk menciptakan, mengkomunikasikan, dan menyampaikan value proposition. Penulis mengarahkan peserta untuk mengidentifikasi sumber daya utama, baik bersifat fisik atau intelektual seperti pengalaman dan pengetahuan, yang dibutuhkan sesuai dengan jenis layanan wisata yang dikelola. Sebagai contoh, untuk penyedia sewa kamar homestay, sumber daya tersebut adalah kamar-kamar di rumah-rumah penduduk dengan kualifikasi sesuai dengan standar layanan. Ketua pokdarwis menceritakan bahwa ia selalu mengingatkan penyedia homestay untuk menyediakan kamar dengan penerangan yang memadai, ventilasi yang lancar, aliran air dan kebersihan kamar mandi yang layak untuk menjamu tamu, dan sebagainya. Merujuk pada Coes (2014), sumber daya yang bersifat non fisik yang relevan berupa pengalaman dan pengetahuan mengelola hubungan baik dengan agen perjalanan dan pengelola atraksi lokal (ini disebut sebagai business network). Sumber daya lain adalah kemampuan untuk mengembangkan event atau paket-paket wisata. Para pelaku bisnis homestaymenyadari bahwa wisatawan datang ke Dusun Kungkuk karena ada paket wisata, sementara layanan homestay merupakan layanan pendukung. Penulis kemudian mengenalkan sumber daya non fisik lain yang penting jika tahap pengembangan bisnis layanan homestay telah berada pada level lebih maju, yaitu data pelanggan, ekuitas merek, website dan pengelolaannya, serta daftar event atau kegiatan.

\section{Channel}

Coes (2014) menyebutkan bahwa channel menentukan bagaimana suatu institusi bisnis menjalin komunikasi dan menjangkau segmen pelanggan untuk menyampaikan value proposition. Dalam hal cara dan saluran komunikasi ini, penulis menyimpulkan bahwa umumnya masyarakat Dusun Kungkuk peserta diskusi mampu mengidentifikasi media yang digunakan untuk mencapai pelanggan. Hal ini karena penggunaan booklet dan media massa sudah sering mereka gunakan sebagai media promosi. Hanya saja, peserta diskusi perlu diingatkan adanya word of mouth sebagai media efektif untuk menarik wisatawan. Dengan memanfaatkan media massa pula, penulis menyampaikan bahwa jika wisatawan menyukai dan merasa puas atas layanan paket wisata, maka mereka akan sukarela untuk memberikan ulasan dan mengungkapkan kepuasan tersebut melalui media sosial. Tentu saja, hal ini menjadi promosi gratis dan efektif bagi pengembangan wisata di Dusun Kungkuk. Penulis membantu pokdarwis mengembangkan website yang menyediakan berbagai informasi tentang Kampung Wisata Kungkuk, selain menggunakan media sosial yang selama ini dilakukan. Sebagaimana dijelaskan oleh Coes (2014), promosi dan komunikasi melalui website dan media internet mampu menciptakan customer awareness tentang value proposition yang ditawarkan suatu unit usaha.

\section{Cost structure}

Menurut Coes (2014), cost structure (struktur biaya) dan revenue stream (aliran penerimaan) merupakan komponen penting bidang finansial. Mengikuti penjelasan Coes (2014), penulis menjelaskan bahwa sebagai usaha bisnis komersial, maka proses layanan wisata harus menghasilkan penerimaan yang lebih besar dibandingkan biaya. Dalam hal biaya, para peserta 
mengidentifikasi sumber-sumber yang menjadi biaya operasional, termasuk biaya listrik, gas/elpiji, dan perbaikan infrastruktur (costs center). Kemampuan untuk mengidentifikasi ini akan menentukan berapa besarnya profit setelah dibandingkan dengan penerimaan.

\section{Revenue stream}

Coes (2014) menjelaskan bahwa yang dimaksud dengan aliran penerimaan merujuk pada arus kas yang dihasilkan dari setiap segmen bisnis. Artikel tersebut juga menyebutkan pentingnya penentuan harga tertentu untuk menghasilkan aliran penerimaan yang cukup untuk menciptakan keuntungan. Dengan merujuk pada artikel tersebut, penulis menjelaskan perlunya menerapkan strategi-strategi untuk menjaga arus pendapatan di masa datang. Sebagai contoh, untuk wisatawan pengguna homestay, masyarakat Dusun Kungkuk perlu menjelaskan kebijakan ongkos sewa kamar jika pada kunjungan berikutnya wisatawan membawa tamu baru. Atau, kebijakan yang sama-sama meringankan beban kedua belah pihak jika terjadi pembatalan pemesanan sewa kamar. Informasi tentang penetapan biaya tambahan untuk layanan ekstra, misal ongkos mengantar/memandu wisatawan ke tempat atau event khusus juga perlu dijelaskan.

Uraian di atas menunjukkan adanya kemampuan masyarakat Dusun Kungkuk untuk mengikuti tahap pertama dalam PAR, yaitu mengetahui sembilan faktor penentu atau building block dalam konsep business model canvas di setiap jenis usahanya. Menurut Pathumporn \& Nakapaksin (2015) kemampuan ini penting sebelum melangkah pada tahap selanjutnya. Di tahap ini terjadi proses identifikasi kapasitas diri dimana setiap peserta menetapkan informasi atau data awal atau base line. Dengan berdasarkan informasi awal tersebut, para peserta berada pada tahap selanjutnya, yaitu penyampaian pendapat dan harapan atas data base line yang telah teridentifikasi. Tahap inilah yang menarik karena para pelaku wisata Dusun Kungkuk menganalisis dan mengevaluasi alternatif langkah apa saja yang dapat ditempuh untuk mempertahankan kekuatan dan kapasitas diri (strength), mengurangi kelemahan (weakness), mengambil kesempatan untuk maju dan meningkatkan kesejahteraan masyarakat (opportunity), dan mengatasi hambatan (threat). Mengingat jenis usaha masyarakat beragam, maka penulis mengarahkan para peserta untuk mengidentifikasi faktor-faktor utama dan seragam yang dihadapi oleh setiap jenis usaha.

Selanjutnya, penulis mengajak peserta untuk mengikuti tahap kedua PAR, yaitu mengidentifikasi faktor kekuatan, kelemahan, kesempatan dan tantangan (SWOT), serta mengembangkan strategi pengembangan bisnis yang mendukung kelangsungan usaha Kampung Wisata Kungkuk. Peserta menggunakan pengetahuan menjalankan bisnis di masingmasing jenis layanan wisata, dan mengklasifikasikannya ke dalam empat kuadran SWOT Kampung Wisata Kungkuk sebagai suatu institusi usaha. Dengan kata lain, seluruh peserta berkontribusi mengidentifikasi empat faktor SWOT usaha Kampung Wisata Kungkuk dalam mengelola seluruh layanan homestay dan paket wisata.

Setelah mengidentifikasi keempat faktor tersebut, penulis membantu peserta diskusi untuk mengembangkan strategi pengembangan bisnis untuk unit usaha Kampung Wisata Kungkuk. Strategi tersebut dikembangkan dengan mempertimbangkan berbagai paket wisata 
dan layanan yang disediakan masyarakat Dusun Kungkuk. Selanjutnya, penulis menyerahkan kepada masyarakat terkait keputusan strategi mana yang paling relevan dan dipilih masyarakat. Penulis berpesan bahwa strategi yang dipilih adalah strategi yang mampu memecahkan masalah dan relevan untuk merencanakan kesepakatan bersama berdasarkan keinginan dan kemanfaatan program bagi masyarakat lokal. Pengembangan strategi ini merupakan sub tahap terakhir dari implementasi PAR.

Para peserta diskusi menggunakan SWOT dan mengembangkan empat strategi dalam rangka mempertahankan kekuatan dan kapasitas diri masyarakat Dusun Kungkuk. Mengingat para peserta umumnya adalah petani dan pengelola kebun buah, mereka umumnya mandiri. Posisi ini merupakan keuntungan dan kekuatan karena mereka adalah self-employed individual yang pembelajar dan terbiasa mengambil keputusan sendiri dalam melaksanakan usaha. Situasi ini memudahkan intervensi dari tokoh masyarakat atau penggerak wisata dan bisnis untuk mengenalkan informasi dan pelatihan untuk meningkatkan kemampuan pengambilan keputusan bisnis. Hal ini dibutuhkan untuk mengambil kesempatan dari pencanangan dan pengembangan desa-desa wisata di wilayah Kota Batu sebagaimana yang tercantum di dalam dokumen Rencana Strategis Kota Batu (Dinas Pariwisata Kota Batu, 2018). Strategi ini merupakan bentuk dari competitive strategy dimana masyarakat desa menggunakan kekuatan dan keuntungan bersaing dibandingkan dusun atau desa lain (competitive advantage) untuk mengambil keuntungan dari kesempatan yang tercipta (opportunity set) (Nouri, Karbassi, \& Mirkia, 2008).

Konsekuensi dari strategi competitive strategy ini adalah bahwa masyarakat perlu memperkuat posisi key partner. Penulis menekankan pentingnya posisi petani dan pemilik kebun buah apel, jeruk, dan bunga mawar sebagai rekan kerja penting dalam sistem Kampung Wisata Kungkuk. Posisi tersebut sama penting dengan ibu-ibu pengelola penyewaan homestay. Masyarakat desa akhirnya menyadari bahwa setiap individu di kampung wisata tersebut memiliki peran penting dalam meningkatkan skala usaha wisata, sekaligus menjadikan kampung mereka berbeda dan unggul dalam pengembangan kampung wisata di kalangan pemerintah Kota Batu. Terdapat kebersamaan dan rasa sebagai bagian dari masyarakat pengelola kampung wisata.

McMillan \& Chavis (1986) menjelaskan bahwa untuk mengembangkan sense of community dibutuhkan empat faktor, yaitu status sebagai anggota masyarakat, adanya pihak yang dominan dan mempengaruhi, adanya hubungan emosi bersama (shared emotional connection), dan adanya integrasi atas upaya-upaya untuk memenuhi kebutuhan bersama. Di Dusun Kungkuk, setiap anggota pelaku kampung wisata memiliki dan diakui statusnya sebagai anggota masyarakat. Terdapat tokoh masyarakat dan pelopor atau penggerak kampung wisata yang memiliki pengetahuan dan pengalaman yang memadai sehingga mampu menjadi penggerak dan mempengaruhi anggota masyarakat dusun lain agar berpartisipasi sebagai key partnerkampung wisata. Mereka juga memiliki hubungan emosi bersama dan memiliki kemauan untuk berintegrasi untuk memenuhi kebutuhan bersama.

Alternatif strategi selanjutnya adalah strategi invasif (invasive strategy), dimana masyarakat Dusun Kungkuk berusaha mengurangi kekurangan diri (weakness) untuk memanfaatkan kesempatan (opportunity) atas arah kebijakan pengembangan Kota Batu yaitu pembangunan desa-desa wisata. Dari hasil diskusi, masyarakat mengakui adanya kelemahan 
yaitu kurangnya keinginan untuk meningkatkan skala usaha wisata. Pertanian memang menjadi mata pencaharian utama masyarakat, sehingga fokus usaha dan alokasi modal diutamakan pada pertanian. Kelemahan ini didorong pula situasi dimana para pemuda kampung kurang memiliki kemampuan untuk mengelola media promosi usaha wisata. Secara akumulatif, hal ini mengakibatkan keberlangsungan kampung wisata bertumpu pada orang-orang tertentu saja, yaitu tokoh dusun dan penggerak desa wisata. Strategi yang dapat dikembangkan untuk mengatasi kelemahan dan sekaligus memanfaatkan kesempatan adalah dengan melibatkan para warga kampung wisata mengikuti pelatihan dan pendidikan usaha wisata secara aktif. Perlu ada kemauan dari warga untuk mendatangkan para ahli dan meminta adanya pendampingan yang intensif untuk meningkatkan kapasitas sumber daya manusia masyarakat desa (manpower) untuk menggerakkan dan mempertahankan kampung wisata. Sejalan dengan penjelasan Salvatore, Chiodo, \& Fantini (2018), kegiatan masyarakat Dusun Kungkuk yang mengutamakan partisipasi ini menjadi media transisi yang meningkatkan kepercayaan diri dan pengetahuan untuk merencanakan dan mengelola Kampung Wisata.

Untuk menjalankan invasive strategy, para tokoh penggerak wisata perlu mengundang akademisi dan praktisi bisnis untuk meningkatkan kemampuan pemuda desa memahami value proposition dan meningkatkan kualitas proses bisnis. Hjalager \& Madsen (2018) menjelaskan bahwa value proposition ini merupakan tahap identifikasi apa saja yang diinginkan pelanggan. Value proposition dibutuhkan untuk menciptakan pengalaman berharga bagi pelanggan. Tetapi, Hjalager \& Madsen (2018) juga menjelaskan bahwa para pelanggan umumnya kurang memahami pengalaman apa yang akan mereka harapkan untuk dapatkan dari mengunjungi lokasi wisata tertentu. Hal ini dapat dimanfaatkan oleh para pelaku kampung wisata untuk menciptakan value proposition sesuai dengan kemampuan warga pelaku wisata.

Alternatif strategi yang ketiga adalah dengan melakukan diversifikasi yang bertujuan menggunakan faktor-faktor kekuatan (strength) untuk mengatasi tantangan (threat). Kekuatan lain yang dimiliki oleh masyarakat Dusun Kungkuk adalah kebersamaan antar warga. Salah satu pembentuk kebersamaan tersebut adalah bahwa umumnya masyarakat tersebut adalah masyarakat asli yang menjadi generasi kedua dan ketiga yang telah tinggal dan mendiami wilayah tersebut nenek moyang mereka. Sementara, tantangan utama yang dihadapi oleh para pelaku wisata adalah perkembangan teknologi informasi dan pengetahuan tentang penyelenggaraan usaha wisata, upaya standarisasi layanan wisata yang semakin kompleks, serta kurangnya kemampuan untuk menjaga kelangsungan bisnis. Menurut penulis dan berdasarkan diskusi, tantangan ini dapat dihadapi bersama jika semakin banyak generasi muda yang terlibat dalam pengelolaan Kampung Wisata Kungkuk. Penulis menyarankan para penggerak dan tokoh kampung wisata perlu mengajak generasi muda untuk terlibat dalam kegiatan kelompok sadar wisata (pokdarwis). Pokdarwis ini merupakan institusi lokal yang bertugas meningkatkan kepedulian dan tanggung jawab untuk menjamin pelaksanaan desa wisata. Pemerintah telah menggalakkan pokdarwis ini sebagai salah satu pemangku kepentingan penting dalam pembangunan pariwisata sekaligus sebagai bagian dari upaya pemberdayaan masyarakat (Kementerian Pariwisata dan Ekonomi Kreatif, 2012)

Hjalager \& Madsen (2018) menyatakan bahwa dalam konsep game theory, proses budaya 
dan sosial yang terinternalisasi pada proses bisnis yang berlaku di antara para pelaku usaha wisata menjadi faktor pengubah (game changer) terjadinya inovasi model bisnis (business model innovation). Untuk menjalankan strategi ini, tokoh desa dan pelopor kampung wisata perlu menjalankan berbagai taktik proaktif, mengajak para pemuda untuk menjalin koalisi dan hubungan dengan pihak eksternal. Beberapa taktik yang dapat dilakukan adalah melibatkan para pemuda untuk menjalankan promosi, mengajak pemuda untuk terlibat dalam transaksi promosi dan Kerjasama dengan para travel agent melalui berbagai media sosial, mengikutkan mereka dalam pelatihan dan pertemuan dengan tokoh dan penggerak desa wisata di tingkat pemerintah Kota Batu, dan mengajak mereka untuk berdiskusi dan berkoordinasi dengan pebisnis di luar kampung dan para akademisi.

Alternatif strategi yang terakhir adalah strategi defensive (defensive strategy). Strategi ini merupakan pengembangan dari upaya untuk mengurangi kelemahan (weakness) sekaligus untuk mengatasi tantangan (threat). Dorongan aktif dari tokoh desa dan penggerak kampung wisata diperlukan untuk mengurangi kelemahan berupa kurangnya kemauan untuk meningkatkan skala usaha kampung wisata, sekaligus untuk mengatasi tantangan sebagaimana disebutkan sebelumnya. Akan tetapi, dengan arah kebijakan pembangunan Kota Batu pada pengembangan desa wisata, tampaknya strategi ini tidak disarankan untuk dilaksanakan. Kampung Wisata Kungkuk di masa datang akan menghadapi persaingan karena desa dan kampung lain di Kota Batu sedang berbenah untuk menjadikan desa dan kampungnya menjadi desa dan kampung wisata pula. Menurut Hjalager \& Madsen (2018), industri pariwisata adalah sektor yang mudah untuk diobservasi dan ditiru pesaing. Untuk itu, tokoh masyarakat dan penggerak wisata di Kampung Wisata Dusun Kungkuk tetap harus berkreasi untuk memenuhi kebutuhan dan keinginan pelanggan serta memiliki kinerja ekonomis yang baik. Pengembangan kreasi dan inovasi paket wisata disesuaikan dengan kemampuan masyarakat Dusun Kungkuk.

Penulis juga menyampaikan bahwa kemampuan masyarakat untuk mempertahankan kampung wisata ditentukan oleh kemampuan masyarakat sebagai pelaku wisata untuk beradaptasi dengan perubahan lingkungan. Hal ini sesuai dengan pendapat Napolitano, Marino, \& Ojala (2015) bahwa sensitifitas unit bisnis terhadap perubahan lingkungan menjadikan faktor katalis kemampuan unit bisnis tersebut untuk menjaga keberlangsungan bisnis dalam jangka panjang. Perubahan yang menonjol adalah berkembangnya desa wisata baru sebagai hasil dari kebijakan pembangunan pariwisata di wilayah kota dan kondisi pandemi. Kedua faktor tersebut berpotensi pada penurunan jumlah wisatawan yang datang dan mengancam kelangsungan bisnis Kampung Wisata Dusun Kungkuk. Kedua faktor tersebut mampu menggugah kesadaran masyarakat untuk memacu motivasi dan kemauan mempertahankan proses bisnis kampung wisata sekaligus meningkatkan kesejahteraan masyarakat. untuk itu, penulis mengajak pemuda pelaku usaha wisata tersebut untuk mengembangkan kesepakatan tentang langkah dan strategi apa yang harus diambil untuk menjaga dinamika dan kelangsungan usaha kampung wisata. 


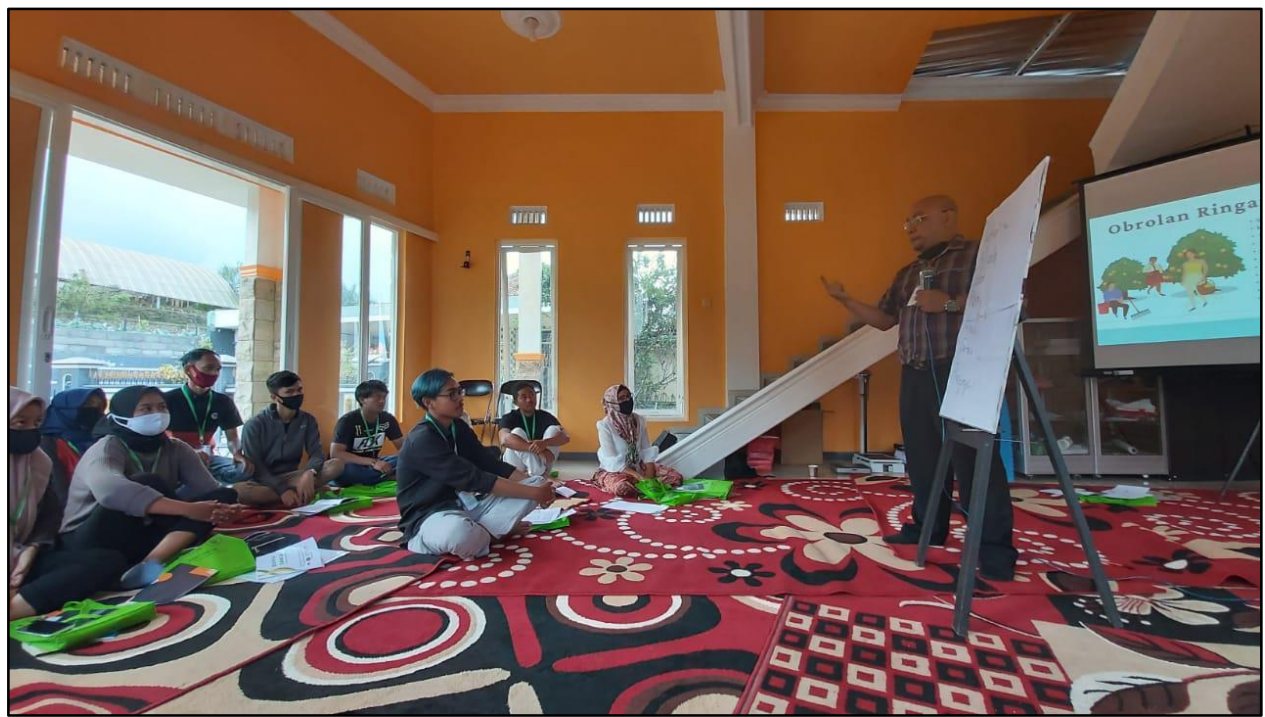

Gambar 1. Sarasehan dan diskusi Business Model Canvas

\section{Kesimpulan}

Metode PAR relevan dalam pelaksanaan pengabdian masyarakat ini karena metode ini mampu mengakomodasi kebutuhan masyarakat Kampung Wisata Kungkuk untuk mengidentifikasi faktor penentu pengembangan kapasitas warga masyarakat untuk menjalankan program-program kampung wisata secara bersama-sama. Dengan kebersamaan tersebut, terbentuklah kepemilikan bersama (shared ownership), bahwa masalah ini adalah masalah masyarakat Dusun Kungkuk secara bersama, yang harus dipecahkan secara bersama oleh masyarakat, untuk kemaslahatan seluruh anggota masyarakat. Metode ini mampu mengajak masyarakat mengidentifikasi dan menganalisis sumber daya yang mereka miliki dan menentukan langkah-langkah strategis untuk mengelola kampung wisata dalam jangka panjang. Penulis membantu merangkum dan menerjemahkan beragam usulan strategi ke dalam empat strategi pengembangan, yaitu competitive, invasive, diversification, dan defensive strategies. Penulis mengembalikan kepada para pemuda pelaku wisata untuk mengembangkan kesepakatan tentang langkah mana yang diambil untuk menjaga agar pengembangan usaha wisata kampung wisata mereka tetap dinamis dan mencapai kelangsungan usaha (business longevity).

\section{Ucapan Terima Kasih}

Kegiatan ini tidak dapat berjalan baik jika tidak didukung partisipasi aktif masyarakat, tokoh masyarakat Kampung Wisata Kungkuk dan perangkat Desa Punten, Kota Batu.

\section{Referensi}

Beeton, S. (2006). Community Development through Tourism. Collingwood Victoria: Landlinks Press. Coes, B. (2014). Critically Assessing the Strengths and Limitations of the Business Model Canvas. Enschede, Netherlands: University of Twente. 
Dinas Pariwisata Kota Batu. (2018). Sistem Akuntabilitas Kinerja Instansi Pemerintah (SAKIP) Kota Batu. Diakses di: https://batukota.go.id: https://batukota.go.id/upload/sakip/dinparSAKIP\%202018.pdf

Hjalager, A.-M., \& Madsen, E. L. (2018). Business Model Innovation in Tourism: Opportunities and Challenges. Dalam C. Cooper, S. Volo, W. C. Gartner, \& N. Scott, The SAGE Handbook of Tourism Management (hal. 373-389). London: Sage Reference.

Kelly, P. J. (2005). Practical suggestions for community interventions using participatory action research. Public Health Nursing, 22(1), 65-73. https://doi.org/10.1111/j.07371209.2005.22110.x

Koch, T., Selim, P., \& Kralik, D. (2002). Enhancing lives through the development of a community based participatory action research programme. Journal of Clinical Nursing, 11(1), 109-117. https://doi.org/10.1046/j.1365-2702.2002.00563.x

Kementerian Pariwisata dan Ekonomi Kreatif. (2012). Pedoman Kelompok Sadar Wisata. Diakses di: https://www.kemenparekraf.go.id/asset_admin/assets/uploads/media/old_all/1_\%20Pedoman \%20Pokdarwis.pdf

McMillan, D. W., \& Chavis, D. M. (1986). Sense of community: A definition and theory. Journal of Community Psychology, 14(1), 6-23. https://doi.org/10.1002/15206629(198601)14:1\%3C6::AID-JCOP2290140103\%3E3.0.CO;2-I

Napolitano, M. R., Marino, V., \& Ojala, J. (2015). In search of an integrated framework of business longevity. Business History, 577), 955-969. https://doi.org/10.1080/00076791.2014.993613

Nouri, J., Karbassi, A. R., \& Mirkia, S. (2008). Environmental management of coastal regions in the Caspian Sea. International Journal of Environmental Science Technology, 5(1), 43-52.

Pathumporn, J., \& Nakapaksin, S. (2015). Participatory action research model for sustainable community-based tourism development. International Journal of Business and Administrative Studies, 1(3), 89-93. doi: 10.20469/ijbas.10002-3

Salvatore, R., Chiodo, E., \& Fantini, A. (2018). Tourism transition in peripheral rural areas: Theories, issues and strategies. Annals of Tourism Research, 68, 41-51. doi:10.1016/j.annals.2017.11.003

Sharpley, R. (2002). Rural tourism and the challenge of tourism diversification: the case of Cyprus. Tourism Management, 23, 233-244. doi:10.1016/S0261-5177(01)00078-4

Spirou, C. (2011). Urban Tourism and Urban Change: Cities in a Global Economy. New York: Routledge.

Steyn, J., Rampa, M., \& Marais, M. (2013). Participatory development of ICT entrepreneurship in an informal settlement in South Africa. The Journal of Community Informatics, 9(4), 1-16.

Strulak-Wojcikiewicz, R., Wagner, N., Lapko, A., \& Hacia, E. (2020). Applying the business model canvas to design the e-platform for sailing tourism. 24th International Conference on Knowledge-Based and Intelligent Information \& Engineering Systems. 176, hal. 1643-1651. Szczecin, Poland: Procedia Computer Science. doi:10.1016/j.procs.2020.09.188 